\title{
Factors affecting production of the group A streptococcus bacteriocin SA-FF22
}

\author{
R. W. JACK and J. R. TAGG \\ Department of Microbiology, University of Otago, PO Box 56, Dunedin, New Zealand
}

\begin{abstract}
Summary. Factors influencing the production of streptococcin A-FF22 (SA-FF22) in liquid media were examined. Despite good growth of the producer strain, no SA-FF22 was detected during incubation at $40^{\circ} \mathrm{C}$, at $\mathrm{pH} 7$, in Brain Heart Infusion Broth or in $\mathrm{Mg}^{2+}$-supplemented media. Optimal SA-FF22 production occurred at $32^{\circ} \mathrm{C}$, at $\mathrm{pH} 6.7$, in cultures in Tryptic Soy Broth supplemented with glucose $2.25 \%$ and yeast extract $1 \%$. Under these conditions SAFF22 remained cell-associated but could be extracted with acid.
\end{abstract}

\section{Introduction}

Bacteriocins are protein antibiotics with bactericidal activity principally against strains of species that are the same or closely related to the producer bacterium. ${ }^{1}$ The first bacteriocin to be isolated from Streptococcus pyogenes was streptococcin A-FF22. ${ }^{2}$ This is a trypsin-sensitive 8 -Kda molecule of $\mathrm{pI}>7 \cdot 5 .^{3}$ Detection of SA-FF22 activity in vitro appeared to depend upon the cultivation of $S$. pyogenes strain FF22 in media that were poor for streptococcal proteinase production. ${ }^{4}$ Several other factors, including growth at higher temperature or alkaline $\mathrm{pH}$, interfered with bacteriocin production. It was noted that SA-FF22 appeared to be very similar to nisin, the wellcharacterised peptide antibiotic of Lactococcus lactis. ${ }^{5}$

$\beta$-Haemolytic streptococci can be typed (P-production type) according to the activity of their bacteriocinlike inhibitory substances (BLIS) ${ }^{6}$ against standard indicators, and under the usual test conditions the Ptype code of strain FF22 is $476 .^{7}$ Strains of particular P-type designations generally occur only within a single species of streptococcus and sometimes only within a single M-serotype. ${ }^{7}$ Indeed, most P-type 476 $S$. pyogenes isolates are of M-type 49 , a serotype commonly associated with acute glomerulonephritis. ${ }^{8}$ Other studies have indicated a generally high incidence of BLIS production in the common nephritis-associated streptococcal serotypes. ${ }^{9}$ Also, it was shown that SA-FF22 exhibits specific toxicity for mammalian myocytes in vitro, prompting speculation about a possible role for $S$. pyogenes BLIS in the pathogenesis of rheumatic carditis. ${ }^{10}$ Subsequently, it has been reported that uncharacterised streptococcal cationic peptides bind to basement membranes in heart and kidney tissue. ${ }^{11,12}$ In view of this putative association between BLIS production and the development of

Received 25 Feb. 1991; revised version accepted 14 May 1991 sequelae to $S$. pyogenes infections, we have examined factors affecting SA-FF22 production in vitro as a preliminary to the purification and further chemical and biological characterisation of the peptide.

\section{Materials and methods}

\section{Bacterial strains}

These were maintained at $-70^{\circ} \mathrm{C}$ in skim milk $10 \%$ and were periodically revived by culture on blood agar. S. pyogenes strain FF22 (M-type 52, T-pattern $3 / 13$ ) was subcultured no more than twice on blood agar before fresh inocula were taken from the frozen stock. The nine standard indicator organisms $\left(\mathrm{I}_{1}-\mathrm{I}_{9}\right)$ used for P-typing have been described previously. ${ }^{7}$ The nisin-producing strain L. lactis CE24 (AFRC 1404; National Collection of Food Bacteria, Institute of Food Research, Reading, Berks.) was a gift from G. W. Tannock (Department of Microbiology, University of Otago, Dunedin).

\section{Media and chemicals}

Tryptic Soy Broth (TSB), Yeast Extract, ToddHewitt Broth (THB), Brain Heart Infusion (BHI) Broth, Skim Milk and Neopeptone were from Difco, glucose from Serva, DNase Test Agar from BBL and RPMI culture medium from Sigma. Chemically defined medium (CDM) was prepared as outlined previously. ${ }^{13}$ Blood agar was Columbia Agar Base (CAB; Gibco), supplemented with human blood $5 \% \mathrm{v} / \mathrm{v}$. Detection of DNAase, amylase, streptococcal proteinase and haemolysin activities was as described previously. ${ }^{14}$

Metal salts $\left(\mathrm{CdSO}_{4} .8 \mathrm{H}_{2} \mathrm{O}, \quad \mathrm{CoCl}_{2} .6 \mathrm{H}_{2} \mathrm{O}\right.$, $\mathrm{FeSO}_{4} .7 \mathrm{H}_{2} \mathrm{O}, \quad \mathrm{Fe}\left(\mathrm{NO}_{3}\right)_{3} .9 \mathrm{H}_{2} \mathrm{O}, \quad \mathrm{MnSO}_{4} \cdot 4 \mathrm{H}_{2} \mathrm{O}$, $\mathrm{MgSO}_{4} .7 \mathrm{H}_{2} \mathrm{O}$ and $\mathrm{ZnSO}_{4} .7 \mathrm{H}_{2} \mathrm{O}$ ) were obtained from 
BDH Chemicals Ltd, Poole. Purified nisin was a gift from Aplin and Barrett Ltd, Beaminster, Dorset.

\section{Deferred antagonism test}

This test was performed essentially as described previously ${ }^{7}$ but was modified to include the use of blood agar supplemented with $\mathrm{CaCO}_{3} 0.5 \% \mathrm{w} / \mathrm{v}$ and, in some cases, metal salts. Incubation conditions are given in the Results. Briefly, after overnight incubation of a diametric streak culture of the BLIS producer strain, the growth was removed and the surface of the culture medium was sterilised by exposure to chloroform vapour. The indicators were then inoculated across the agar at right angles to the line of the original producer culture. After incubation the presence of BLIS was indicated by inhibition of growth of indicators in the region of the cross-streak.

\section{Acid extraction of cell-associated bacteriocin $S A$ - FF 22}

S. pyogenes strain FF22 cells grown under appropriate conditions were harvested by centrifugation at $3500 \mathrm{~g}$ for $15 \mathrm{~min}$, washed twice in $5 \mathrm{~mm}$ phosphate buffer, $\mathrm{pH} 6 \cdot 8$, and resuspended to one-fifth of the original culture volume in $\mathrm{NaCl} 0.85 \%$ containing $50 \mathrm{mM} \mathrm{HCl}$. After $18 \mathrm{~h}$ at $4^{\circ} \mathrm{C}$, the cells were removed by centrifugation and the bacteriocin-containing supernatant fluid was adjusted to $\mathrm{pH} 6 \cdot 5-6 \cdot 8$ with $1 \mathrm{M}$ $\mathrm{NaOH}$.

\section{Assay of bacteriocin SA-FF22 activity}

Doubling dilutions of bacteriocin-containing supernates in phosphate-buffered saline, $\mathrm{pH} 6 \cdot 8$, (PBS) were prepared in microtitration-tray wells and $20 \mu$ of each dilution was applied to the surface of well-dried CAB plates of uniform thickness. After this had dried, the surface of the medium was sterilised by exposure to chloroform vapour for $30 \mathrm{~min}$. The plates were exposed to air and the agar surface was then flooded with a 100 -fold dilution of an overnight THB culture of the appropriate indicator strain. The excess fluid was decanted and the plates were incubated for $18 \mathrm{~h}$ at $37^{\circ} \mathrm{C}$ in $\mathrm{CO}_{2} 5 \%$ in air. The titre of inhibitory activity was defined as the highest dilution of the sample that produced a well-defined inhibition zone on the indicator lawn. This dilution of the sample was said to contain, by definition, one arbitrary unit (AU) of bacteriocin $/ \mathrm{ml}$.

In this study the titre of SA-FF22 was routinely measured against indicator strain $\mathrm{I}_{8}$. The specificity of the inhibitory activity was assessed by comparing this titre with that of samples measured against strain FF22, which has specific immunity to SA-FF22, and a "cured" derivative of strain FF22 (designated EB1) which has lost both SA-FF22 production and immunity characters.

\section{Estimation of wet-cell mass}

Ten-ml volumes of cultures were centrifuged in preweighed tubes, and the cell pellets were washed twice in cold $5 \mathrm{~mm}$ phosphate buffer $(\mathrm{pH} \mathrm{7.0)}$ and then collected by centrifugation $\left(16000 \mathrm{~g}, 10 \mathrm{~min}, 4^{\circ} \mathrm{C}\right)$. The tubes were drained thoroughly, re-weighed and the wet-cell mass was determined by subtraction.

\section{Streptococcal extracellular proteinase}

Proteinase activity was measured with casein as substrate. ${ }^{15}$ Proteinase production was inhibited by the addition to liquid culture media of iodoacetic acid to a final concentration of $50 \mu \mathrm{M}$. $^{16}$

\section{Assay of protein and carbohydrate}

The protein content of samples was assayed against a standard curve of bovine serum albumin (Sigma). ${ }^{17}$ Total reducing sugars were estimated by the $\rho$ hydroxybenzoic acid hydrazide (Sigma) colourimetric method, ${ }^{18}$ with D-glucose (Serva) as a standard.

\section{Determination of magnesium concentration}

Known triplicate volumes $(5-10 \mathrm{ml})$ of the test medium were dried to completion at $80^{\circ} \mathrm{C}$ in nitric acid-washed crucibles. Samples were dry-ashed for $18 \mathrm{~h}$ at $350^{\circ} \mathrm{C}$, resuspended in $10 \mathrm{ml}$ of nitric acid $1 \%$ $\mathrm{v} / \mathrm{v}$ and filtered through nitric acid-washed membrane filters of $0.45 \mu \mathrm{m}$ pore size. Magnesium in the samples was estimated in a Varian Techtron model AA6 Atomic Absorption Spectrophotometer by comparison with a standard curve of dilutions of a stock of magnesium in water $(1 \mathrm{mg} / \mathrm{ml})$.

\section{Removal of magnesium from media}

Chelex resin (Sigma) was mixed with the liquid medium $(1: 25 \mathrm{w}: \mathrm{v})$ for $18 \mathrm{~h}$ at $4^{\circ} \mathrm{C}$ to adsorb magnesium ions and the resin was removed by centrifugation at $500 \mathrm{~g}$ for $5 \mathrm{~min} .{ }^{19}$

\section{Batch fermenter cultures}

A bioflo model C30 $500 \mathrm{ml}$ fermenter (New Brunswick Scientific, New Brunswick, NJ, USA) fitted with a $\mathrm{pH}$ controller and an Ingold autoclavable $\mathrm{pH}$ electrode (Ingold Electrodes Inc., Andover, MA, USA) was used in these studies.

\section{Results}

\section{Inhibitor production by strain FF22 on solid media}

The inhibitory spectrum of strain FF22 against the nine standard indicators changed when the incubation conditions or the composition of the test medium were altered (table I). The inhibitory activity against indi- 
Table I. Inhibitory activity of strain FF22 in deferred antagonism tests on CAB-based media under aerobic and anaerobic incubation conditions

\begin{tabular}{|c|c|c|c|c|c|c|c|c|c|c|c|}
\hline \multirow{2}{*}{$\begin{array}{l}\text { Culture } \\
\text { medium }\end{array}$} & \multirow{2}{*}{$\begin{array}{l}\text { Incubation } \\
\text { atmosphere }\end{array}$} & \multicolumn{9}{|c|}{ Inhibitory activity against indicator strain } & \multirow{2}{*}{ P-type } \\
\hline & & $I_{1}$ & $\mathrm{I}_{2}$ & $\mathrm{I}_{3}$ & $\mathrm{I}_{4}$ & $\mathbf{I}_{5}$ & $\mathrm{I}_{6}$ & $\mathbf{I}_{7}$ & $\mathrm{I}_{8}$ & $\mathrm{I}_{9}$ & \\
\hline $\mathrm{CAB}$ & $\begin{array}{l}\text { Aer } \\
\text { Anaer }\end{array}$ & $\begin{array}{l}+++ \\
+++\end{array}$ & - & $\begin{array}{l}- \\
-\end{array}$ & $\overline{+}$ & $\begin{array}{l}+++ \\
+++\end{array}$ & $\begin{array}{l}+++ \\
+++\end{array}$ & $\begin{array}{l}+++ \\
+++\end{array}$ & $\begin{array}{l}+++ \\
+++\end{array}$ & $\begin{array}{l}- \\
-\end{array}$ & $\begin{array}{l}436 \\
676\end{array}$ \\
\hline $\mathrm{CAB}+$ blood & $\begin{array}{l}\text { Aer } \\
\text { Anaer }\end{array}$ & $\begin{array}{l}+++ \\
+++\end{array}$ & $\begin{array}{l}- \\
++\end{array}$ & - & $\overline{+}$ & $\begin{array}{l}+++ \\
+++\end{array}$ & $\begin{array}{l}+++ \\
+++\end{array}$ & $\begin{array}{l}+++ \\
+++\end{array}$ & $\begin{array}{l}+++ \\
+++\end{array}$ & - & $\begin{array}{l}436 \\
676\end{array}$ \\
\hline $\begin{array}{l}\mathrm{CAB}+\text { blood } \\
+\mathrm{CaCO}_{3}\end{array}$ & $\begin{array}{l}\text { Aer } \\
\text { Anaer }\end{array}$ & $\begin{array}{l}+++ \\
+++\end{array}$ & - & $\begin{array}{l}- \\
-\end{array}$ & $\overline{+}$ & $\begin{array}{l}+++ \\
+++\end{array}$ & $\begin{array}{l}+++ \\
+++\end{array}$ & $\begin{array}{l}+++ \\
+++\end{array}$ & $\begin{array}{l}++t \\
++t\end{array}$ & $\begin{array}{l}- \\
-\end{array}$ & $\begin{array}{l}436 \\
476\end{array}$ \\
\hline $\begin{array}{l}\text { CAB + blood } \\
+\mathrm{Mg}^{2+*}\end{array}$ & $\begin{array}{l}\text { Aer } \\
\text { Anaer }\end{array}$ & - & $\begin{array}{c}- \\
++\end{array}$ & $\begin{array}{l}- \\
-\end{array}$ & $\begin{array}{l}- \\
-\end{array}$ & $\begin{array}{l}- \\
-\end{array}$ & $\begin{array}{l}- \\
-\end{array}$ & + & - & $\begin{array}{l}- \\
-\end{array}$ & $\begin{array}{l}000 \\
204\end{array}$ \\
\hline $\begin{array}{l}\mathrm{CAB}+\text { blood }+ \\
\mathrm{CaCO}_{3}+\mathrm{Mg}^{2+}\end{array}$ & $\begin{array}{l}\text { Aer } \\
\text { Anaer }\end{array}$ & - & - & - & - & - & $\begin{array}{l}- \\
-\end{array}$ & $\begin{array}{l}- \\
-\end{array}$ & $\begin{array}{l}- \\
-\end{array}$ & - & $\begin{array}{l}000 \\
000\end{array}$ \\
\hline
\end{tabular}

Aer, air; Anaer, anaerobic $\left(\mathrm{CO}_{2} 5 \%, \mathrm{H}_{2} 10 \%, \mathrm{~N}_{2} 85 \% ;+,++,+++\right.$, relative size of inhibition zone; ${ }^{7}-$, no inibition of indicator growth.

* Final concentration $1 \mathrm{mM}$

cators $\mathrm{I}_{2}$ and $\mathrm{I}_{4}$ appeared to be increased under anaerobic conditions. This enhanced production of inhibitory activity against $I_{2}$ (strain FF22) did not occur when $\mathrm{CaCO}_{3} 0.5 \% \mathrm{w} / \mathrm{v}$ had been added to the test medium to reduce acid-mediated inhibitory effects.

The nisin-producing strain, L. lactis CE24, produced inhibitory activity with the same P-type code as strain FF22 when tested on blood agar under anaerobic conditions. However, unlike strain FF22, its activity against indicator $\mathrm{I}_{2}$ was not reduced by the presence of $\mathrm{CaCO}_{3}$ in the test medium.

The addition to blood agar of the metal ions $\mathrm{Ca}^{2+}$, $\mathrm{Cu}^{2+}, \mathrm{Fe}^{2+}, \mathrm{Fe}^{3+}, \mathrm{Mn}^{2+}$ or $\mathrm{Zn}^{2+}$ to a concentration of $1 \mathrm{mM}$ had no effect on SA-FF22 production in deferred antagonism tests. However, when $1 \mathrm{mM}$ $\mathrm{Mg}^{2+}$ was present in the blood agar, only indicators $I_{2}$ and $I_{7}$ were inhibited after growth of strain FF22 under anaerobic conditions and no indicator was inhibited after aerobic growth (table I). Supplementation of the $\mathrm{Mg}^{2+}$-containing blood agar with $\mathrm{CaCO}_{3}$ $0.5 \%$ resulted in no inhibitory activity being detected in aerobic or anaerobic conditions. By contrast, nisin production by $L$. lactis CE24 did not appear to be affected by any of these metal ion supplements.

DNAase, amylase, proteinase and haemolysin production by strain FF22 on DNase agar, CAB, Skim Milk Agar and Blood Agar respectively was not affected by their supplementation with $1 \mathrm{mM} \mathrm{Mg}^{2+}$.

\section{$S A-F F 22$ production in small volume liquid cultures}

Comparison of the suitability of several nutrient media and a chemically defined medium for inhibitor production by strain FF22 (table II) showed that it occurred only in TSB and THB. Because the highest recovery was from TSB, a series of modifications to this medium were evaluated for their effect on SAFF22 yield.
Although diluting the TSB growth medium to $50 \%$ $\mathrm{v} / \mathrm{v}$ in distilled water increased the specific activity of both the extracellular and acid-extractable SA-FF22 in the culture, the total inhibitor yield was less than from cultures in undiluted TSB. Doubling the concentration of the TSB medium decreased the specific activity of SA-FF22 and did not increase the yield. The effects of various combinations of the nutrient supplements were evaluated and the highest yield and specific activity of SA-FF22 was obtained with TSB containing glucose $1 \%$ and yeast extract $1 \%$. None of the combinations of glucose, yeast extract or neopeptone, when added to BHI, RPMI or CDM, resulted in any detectable production of SA-FF22. Addition of glucose and yeast extract to TSB at concentrations above $1 \%$ did not increase further the yield of SAFF22.

By combining volumes of BHI and TSB in different proportions (BHI:TSB = 5:95, 10:90, 15:85, 20:80, $25: 75$ and $30: 70 \% \mathrm{v} / \mathrm{v}$ ) it was demonstrated that when the hybrid medium contained $\mathrm{BHI}>20 \%$ neither cellassociated nor extracellular SA-FF22 activity could be detected. Assay of SA-FF22 in TSB culture supernates with BHI, TSB or PBS as diluent, did not change the titre of its inhibitory activity.

The effect of the incubation atmosphere and temperature on SA-FF22 production in TSB was evaluated (table III). The changes to the atmosphere did not appear to affect SA-FF22 yield; however, increasing the incubation temperature to $40^{\circ} \mathrm{C}$, while without effect on the terminal $\mathrm{pH}$ and proteinase activity of the cultures, prevented formation of the inhibitor. No increase in the yield of SA-FF22 was detected in TSB, THB, BHI, RPMI and CDM cultures when proteinase production was inhibited by $50 \mu \mathrm{M}$ iodoacetic acid.

The addition of $1 \mathrm{~mm} \mathrm{Mg}^{2+}$ prevented production of SA-FF22 yet appeared to have no effect on the growth of strain FF22 in TSB. The SA-FF22 titre of culture supernates was the same when assayed on 
Table II. Medium composition and its effect on the yield of SA-FF22 in broth cultures at $37^{\circ} \mathrm{C}$

\begin{tabular}{|c|c|c|c|c|c|c|}
\hline \multirow{2}{*}{$\begin{array}{l}\text { Culture } \\
\text { medium }\end{array}$} & \multirow[b]{2}{*}{$\mathrm{pH}^{*}$} & \multirow{2}{*}{$\begin{array}{l}\text { Proteinase activity } \\
(\mathrm{U} / \mathrm{ml}) \text { in supernate }\end{array}$} & \multicolumn{2}{|c|}{ SA-FF22 activity in supernate } & \multicolumn{2}{|c|}{ SA-FF22 activity in acid extract $\dagger$} \\
\hline & & & $\begin{array}{c}\text { titre } \\
(\mathrm{AU} / \mathrm{ml})\end{array}$ & $\begin{array}{c}\text { specific activity } \\
\text { (AU/mg of protein) }\end{array}$ & $\begin{array}{c}\text { titre } \\
(\mathrm{AU} / \mathrm{ml})\end{array}$ & $\begin{array}{c}\text { specific activity } \\
\text { (AU/mg of protein) }\end{array}$ \\
\hline TSB & $5 \cdot 4$ & $1 \cdot 1$ & 4 & 0.44 & 8 & $11 \cdot 4$ \\
\hline THB & 5.9 & 1.6 & 2 & 0.20 & 4 & 6.7 \\
\hline $\mathrm{BHI}$ & $5 \cdot 9$ & 4.9 & 0 & ND & 0 & ND \\
\hline RPMI & $5 \cdot 1$ & $2 \cdot 3$ & 0 & ND & 0 & ND \\
\hline CDM & $5 \cdot 2$ & $2 \cdot 1$ & 0 & ND & 0 & ND \\
\hline $\begin{array}{l}50 \% \text { TSB } \\
\times 2 \text { TSB }\end{array}$ & $\begin{array}{l}5 \cdot 8 \\
5 \cdot 2\end{array}$ & $\begin{array}{l}0 \cdot 3 \\
1 \cdot 2\end{array}$ & $\begin{array}{l}2 \\
4\end{array}$ & $\begin{array}{l}0 \cdot 54 \\
0.28\end{array}$ & $\begin{array}{l}4 \\
8\end{array}$ & $\begin{array}{r}20 \cdot 0 \\
3 \cdot 5\end{array}$ \\
\hline TSB + glucose & 4.8 & 1.4 & 4 & 0.41 & 8 & $13 \cdot 3$ \\
\hline TSB + yeast extract & $5 \cdot 5$ & $1 \cdot 4$ & 4 & $0 \cdot 36$ & 8 & $8 \cdot 0$ \\
\hline TSB + Neopeptone & $6 \cdot 0$ & 0.9 & 8 & $0 \cdot 60$ & 16 & $13 \cdot 3$ \\
\hline $\begin{array}{c}\text { TSB + glucose + } \\
\text { yeast extract }\end{array}$ & $5 \cdot 0$ & $1 \cdot 2$ & 8 & $0 \cdot 70$ & 16 & $14 \cdot 5$ \\
\hline $\begin{array}{l}\text { TSB + glucose }+ \\
\text { Neopeptone }\end{array}$ & $5 \cdot 2$ & $0 \cdot 6$ & 8 & 0.63 & 16 & $12 \cdot 3$ \\
\hline
\end{tabular}

ND, not determined.

* After incubation for $18 \mathrm{~h}$.

$\dagger$ Acid extract ( $\mathrm{vol}=4 \mathrm{ml}$ ) of cell pellet from 20 -ml culture.

$\ddagger$ Glucose, yeast extract and neopeptone were each added to $1 \% \mathrm{w} / \mathrm{v}$.

$\mathrm{CAB}$ and on $\mathrm{CAB}$ containing $1 \mathrm{mM} \mathrm{Mg}^{2+}$. Supplementation of active TSB supernates with $1 \mathrm{mM} \mathrm{Mg}^{2+}$ for $24 \mathrm{~h}$ at $4^{\circ} \mathrm{C}$ caused no change in SA-FF22 titre. Media in which the $\mathrm{Mg}^{2+}$ had been removed by treatment with Chelex resin did not support the growth of strain FF22. Subsequent addition of $\mathrm{Mg}^{2+}$ showed that a minimum of $0.02-0.03 \mathrm{mM} \mathrm{Mg}^{2+}$ was necessary for both normal growth and SA-FF22 production in TSB and THB (the unmodified media contain $0.05-$ $0.06 \mathrm{mM} \mathrm{Mg}^{2+}$ ). At $0 \cdot 14-0 \cdot 16 \mathrm{mM} \mathrm{Mg}^{2+}$, cell growth did not appear to be inhibited, but there was no detectable production of SA-FF22. No SA-FF22 production could be detected in BHI, RPMI and CDM even when the level of $\mathrm{Mg}^{2+}$ in these media had been adjusted to approximately $0.05 \mathrm{~mm}$ before inoculation with strain FF22.

\section{Fermenter cultures}

Extra glucose (final concentration $2 \cdot 5 \%$ ) was incor- porated into TSB to sustain the additional growth of strain FF22 that could be obtained in pH-controlled fermenter cultures (table IV). With the $\mathrm{pH}$ controlled at $7 \cdot 2$ (the initial $\mathrm{pH}$ of the medium) no SA-FF22 was produced, whereas the total yield from cultures grown at $\mathrm{pH} 6.7,6.2$ and 4.8 was proportional to the cell mass. At pH 6.7, all SA-FF22 appeared to be cell associated. The SA-FF22 activity released extracellularly during the growth of cultures at $\mathrm{pH} 6 \cdot 2$ (or lower) was not readsorbed to the cells when the $\mathrm{pH}$ was adjusted to $6 \cdot 7$.

The effect of incubation temperature on growth and production of SA-FF22 in fermenter cultures is summarised in table $\mathrm{V}$. The highest yield of SA-FF22 was obtained at $32^{\circ} \mathrm{C}$. Incubation at $40^{\circ} \mathrm{C}$ prevented SA-FF22 production but did not substantially alter either the total cell yield or the amount of proteinase produced. Incubation of SA-FF22-containing supernates at $40^{\circ} \mathrm{C}$ for $18 \mathrm{~h}$ resulted in no loss of inhibitory activity.

Table III. The effects of incubation atmosphere and temperature on the production of SA-FF22 in TSB cultures

\begin{tabular}{|c|c|c|c|c|c|}
\hline \multirow{2}{*}{$\begin{array}{l}\text { Incubation } \\
\text { atmosphere }\end{array}$} & \multirow{2}{*}{$\begin{array}{c}\text { Temp } \\
\left({ }^{\circ} \mathrm{C}\right)\end{array}$} & \multirow{2}{*}{$\mathrm{pH}^{*}$} & \multicolumn{2}{|c|}{ SA-FF22 activity $(\mathrm{AU} / \mathrm{ml})$ in } & \multirow{2}{*}{$\begin{array}{l}\text { Proteinase activity } \\
\qquad(\mathrm{U} / \mathrm{ml})\end{array}$} \\
\hline & & & supernate $†$ & acid extract $\ddagger$ & \\
\hline Air & $\begin{array}{l}32 \\
37 \\
40\end{array}$ & $\begin{array}{l}5 \cdot 4 \\
5 \cdot 3 \\
5 \cdot 3\end{array}$ & $\begin{array}{l}4 \\
4 \\
0\end{array}$ & $\begin{array}{l}8 \\
8 \\
0\end{array}$ & $\begin{array}{l}1 \cdot 0 \\
1 \cdot 1 \\
1 \cdot 1\end{array}$ \\
\hline $\mathrm{CO}_{2} 5 \%$ in air & 37 & $5 \cdot 3$ & 4 & 8 & $1 \cdot 2$ \\
\hline Anaerobic & $\begin{array}{l}32 \\
37\end{array}$ & $\begin{array}{l}5 \cdot 3 \\
5 \cdot 3\end{array}$ & $\begin{array}{l}4 \\
4\end{array}$ & $\begin{array}{l}8 \\
8\end{array}$ & $\begin{array}{l}1 \cdot 3 \\
1 \cdot 3\end{array}$ \\
\hline
\end{tabular}

* After growth for $18 \mathrm{~h}$.

$\dagger$ Culture supernate, $\mathrm{vol}=20 \mathrm{ml}$.

$\ddagger$ Acid extract $(\mathrm{vol}=4 \mathrm{ml})$ of cell pellet from 20 - $\mathrm{ml}$ culture. 
Table IV. SA-FF22 production in fermenter cultures* maintained at constant $\mathrm{pH}$ and at $32^{\circ} \mathrm{C}$

\begin{tabular}{|c|c|c|c|c|}
\hline \multirow{2}{*}{$\mathrm{pH}$} & \multicolumn{2}{|c|}{ SA-FF22 activity $(\mathrm{AU} / \mathrm{ml})$ in } & \multirow{2}{*}{$\begin{array}{c}\text { Cell mass } \S \\
(\mathrm{mg} / \mathrm{ml})\end{array}$} & \multirow{2}{*}{$\begin{array}{l}\text { Proteinase activity } \\
\qquad(\mathrm{U} / \mathrm{ml})\end{array}$} \\
\hline & supernate $\dagger$ & acid extract $\ddagger$ & & \\
\hline $7 \cdot 2$ & 0 & 0 & $25 \cdot 2$ & 0.6 \\
\hline $6 \cdot 7$ & 0 & 128 & 25.0 & 0.9 \\
\hline $6 \cdot 2$ & 16 & 32 & $24 \cdot 7$ & $1 \cdot 1$ \\
\hline $4 \cdot 8$ & 8 & 16 & $15 \cdot 6$ & $1 \cdot 3$ \\
\hline
\end{tabular}

\footnotetext{
* TSB $(500 \mathrm{ml})+$ glucose $2 \cdot 25 \% \mathrm{w} / \mathrm{v}+$ yeast extract $1 \% \mathrm{w} / \mathrm{v}$. $+\mathrm{Vol}=500 \mathrm{ml}$.

$\$$ Acid extract $(\mathrm{vol}=100 \mathrm{ml})$ of cell pellet from $500-\mathrm{ml}$ culture

$\S$ Wet weight $(\mathrm{mg})$ of cells from $1 \mathrm{ml}$ of culture.
}

Table V. Effect of growth temperature of strain FF22 on the yield of SA-FF22 in fermenter cultures

\begin{tabular}{|c|c|c|c|c|c|c|c|c|}
\hline \multirow{3}{*}{$\begin{array}{c}\text { Temp } \\
\left({ }^{\circ} \mathrm{C}\right)\end{array}$} & \multicolumn{4}{|c|}{ Fermenter controlled at pH 6.7} & \multicolumn{4}{|c|}{ Fermenter without $\mathrm{pH}$ control } \\
\hline & \multicolumn{2}{|c|}{ SA-FF22 activity $(\mathrm{AU} / \mathrm{ml})$ in } & \multirow{2}{*}{$\begin{array}{l}\text { Cell mass } \\
(\mathrm{mg} / \mathrm{ml})\end{array}$} & \multirow{2}{*}{$\begin{array}{c}\text { Proteinase } \\
\text { activity } \\
(\mathrm{U} / \mathrm{ml})\end{array}$} & \multicolumn{2}{|c|}{ SA-FF22 activity $(\mathrm{AU} / \mathrm{ml})$ in } & \multirow{2}{*}{$\begin{array}{l}\text { Cell mass } \\
(\mathrm{mg} / \mathrm{ml})\end{array}$} & \multirow{2}{*}{$\begin{array}{c}\text { Proteinase } \\
\text { activity } \\
(\mathrm{U} / \mathrm{ml})\end{array}$} \\
\hline & supernate & acid extract & & & supernate & acid extract & & \\
\hline 32 & 0 & 128 & $25 \cdot 0$ & 0.9 & 8 & 16 & $15 \cdot 6$ & $1 \cdot 1$ \\
\hline 37 & 0 & 64 & $25 \cdot 1$ & $1 \cdot 0$ & 4 & 8 & $15 \cdot 6$ & 1.2 \\
\hline 40 & 0 & 0 & $24 \cdot 8$ & $1 \cdot 1$ & 0 & 0 & 15.9 & $1 \cdot 2$ \\
\hline
\end{tabular}

See footnotes to table IV.

Addition of $0.2 \mathrm{mM} \mathrm{Mg}^{2+}$ to the growth medium (TSB or THB) prevented SA-FF22 production in batch fermenter cultures, whether or not the culture $\mathrm{pH}$ was maintained at $6 \cdot 7$. Also, even with control of $\mathrm{pH}$ at $6 \cdot 7$, strain FF22 cultures in BHI, RPMI and CDM failed to yield any detectable SA-FF22.

The indicator strain specificities of SA-FF22 and nisin were compared by titrating each of these inhibitors against strains $\mathrm{I}_{8}$, FF22 and EB1. SA-FF22 preparations with a titre of 64 on strains $I_{8}$ and $E B 1$ had a titre of only 1 on strain FF22. By comparison, nisin assays give identical titres on all three indicators.

\section{Discussion}

SA-FF22 has previously been reported to closely resemble nisin in many of its physicochemical and biological properties and in the conditions for its production. ${ }^{5}$ However, here we found that $S$. pyogenes strain FF22 and the nisin-producing strain L. lactis CE24 produced different P-type patterns. Strain FF22 was immune to its own inhibitory product (SA-FF22), but sensitive to nisin. This indicated that these inhibitors differed in their specificity of action. In the present study SA-FF22 production was shown to be enhanced by the supplementation of the TSB growth medium with glucose. In this respect SA-FF22 production resembles that of nisin. ${ }^{20}$ By contrast, the production of some other streptococcal bacteriocins such as those of $S$. agalactiae strain $74-628^{21}$ and $S$. salivarius $\mathrm{P}^{22}$ is repressed by addition of glucose to the growth medium.

The addition of $\mathrm{CaCO}_{3}$ to the typing medium altered the P-type pattern of anaerobically incubated strain FF22 cultures, through the loss of inhibitory activity against $I_{2}$ (strain FF22). This result suggested that this "auto-inhibitory" activity of strain FF22 was probably due to acidic metabolic end products, an effect similar to that produced by some other $S$. pyogenes strains when tested by the P-typing procedure. $^{9}$

Proteinase production by strain FF22 is promoted by growth in $\mathrm{BHI}{ }^{4}$ In some cases production of group A streptococcal bacteriocins is favoured by conditions that promote proteinase production. ${ }^{23}$ Since purified streptococcal proteinase inactivates SA-FF22 (results not shown), inhibition of proteinase production should increase the yield of SA-FF22. However, this was not found here.

The incubation temperature influenced SA-FF22 production. The optimum temperature for nisin production is $30^{\circ} \mathrm{C},{ }^{24}$ whereas for Pep $5^{25}$ and streptocin $\mathrm{B}^{21}$ it is $35^{\circ} \mathrm{C}$. $\mathrm{SA}-\mathrm{FF} 22$ resembled streptocin $\mathrm{B} 1$ in that its production was inhibited by growth at elevated temperatures.

Ellwood and Tempest ${ }^{26}$ have shown that the production and secretion of protein by bacteria is affected by a number of factors including $\mathrm{pH}$, concentration and type of ions present, and the growth rate. The increase in growth rate at $40^{\circ} \mathrm{C}$ may explain the lack of production of SA-FF22 at this temperature. 
Alternatively, a temperature-sensitive protein may have a role in the formation of the active inhibitor. Growth at $40^{\circ} \mathrm{C}$ did not cause an irreversible loss of inhibitor-producing capability since a subsequent reduction of the incubation temperature restored the SA-FF22-producing phenotype (results not shown).

Streptococci are solely fermentative in their metabolism and the accumulation of acidic metabolites may often be an important growth-limiting factor. Control of $\mathrm{pH}$ at 6.7 in cultures containing excess glucose resulted in a significant increase in the cell mass and in the yield of cell-associated SA-FF22. By acidextracting cells from such cultures, particularly high recoveries of SA-FF22 may be obtained. A similar approach has been adopted for the large scale production of nisin. ${ }^{27}$

The cell walls of Gram-positive bacteria have been shown to act as cation exchangers, the cation with the highest affinity for the walls being $\mathrm{H}^{+} .{ }^{28}$ One possible mechanism for the observed irreversible elution of SA-FF22 from the producer cells under acidic conditions may be that it is displaced by the increasing concentration of $\mathrm{H}^{+}$as the $\mathrm{pH}$ decreases. The failure of the inhibitor to re-adsorb to the cells when the $\mathrm{pH}$ is raised may reflect the inability of SA-FF22 to displace bound $\mathrm{H}^{+}$. Alternatively, other cell-surface components like lipoteichoic acids may also have been eluted under the acidic conditions, removing potential anionic "sites" for re-association of SA-FF22.

Metal ions regulate the expression of several bacterial extracellular products. Diphtheria toxin production is influenced by iron and possibly by other metals $;{ }^{29}$ toxic shock syndrome toxin 1 of Staphylococcus aureus is influenced by magnesium ${ }^{30}$ and possibly zinc. ${ }^{31}$ Our results, indicating that SA-FF22 production may also be controlled by magnesium concentration, are perhaps the first report of a metal ion specifically affecting bacteriocin production in Grampositive bacteria.

\section{References}

1. Tagg JR, Dajani AS, Wannamaker LW. Bacteriocins of grampositive bacteria. Bacteriol Rev 1976; 40: 722-756.

2. Tagg JR, Read RSD, McGiven AR. Bacteriocine production by group A streptococci. Pathology 1971; 3: 277-278.

3. Tagg JR, Read RSD, McGiven AR. Bacteriocin of a group A streptococcus: partial purification and properties. Antimicrob Agents Chemother 1973; 4: 214-221.

4. Tagg JR, Dajani AS, Wannamaker LW, Gray ED. Group A streptococcal bacteriocin. Production, purification, and mode of action. $J$ Exp Med $1973 ; 138$ : $1168-1183$.

5. Tagg JR, Wannamaker LW. Streptococcin A-FF22: nisin-like antibiotic substance produced by a group A streptococcus. Antimicrob Agents Chemother 1978; 14: 31-39.

6. Tagg JR, Ragland NL, Dickson NP. A longitudinal study of Lancefield group A streptococcus acquisitions by a group of young Dunedin schoolchildren. NZ Med J 1990; 103: 429-431.

7. Tagg JR, Bannister LV. "Fingerprinting" $\beta$-haemolytic streptococci by their production of and sensitivity to bacteriocine-like inhibitors. J Med Microbiol 1979; 12: 397-411.

8. Tagg JR, Skjold SA. A bacteriocin produced by certain M-type 49 Streptococcus pyogenes strains when incubated anaerobically. J Hyg 1984; 93: 339-344.
Because production of haemolysin, amylase, proteinase and DNAase by strain FF22 was not adversely affected by increased levels of magnesium in the media, the inhibition of SA-FF22 production by magnesium was not the result of a general repression of the formation of extracellular products. Furthermore, because the activity of pre-formed SA-FF22 remained unchanged after incubation with magnesium it suggests that there is no direct molecular interaction between the inhibitor and magnesium ions. Growth in high magnesium concentrations did not cause irreversible loss of the SA-FF22-producing phenotype; subculturing cells from high magnesiumcontaining media to media containing non-inhibitory levels of magnesium immediately restored production of SA-FF22 (results not shown). Other experiments showed that the growth rate of strain FF22 was unaffected by the presence of excess magnesium in the culture medium and that the titres of SA-FF22 preparations were identical when assayed on either high magnesium-containing or the usual assay medium. These results indicate that the presence of additional magnesium in the growth medium affects neither the growth of strain FF22 detrimentally nor the sensitivity of the indicator strains to SA-FF22.

The findings from this and other laboratories indicate that in vitro production of BLIS is a common characteristic of streptococci. What remains unclear is the role of BLIS in vivo. Our understanding of the potential contribution of BLIS to the virulence of streptococci and to their interactions with other bacteria in natural ecosystems may be significantly enhanced by studying the factors that influence its production in vitro.

This work was supported by grants from the Medical Research Council of New Zealand and the National Heart Foundation of New Zealand.

9. Tagg JR. Production of bacteriocin-like inhibitors by group A streptococci of nephritogenic M types. J Clin Microbiol $1984 ; 19: 884-887$

10. Tagg JR, McGiven AR. Some possible autoimmune mechanisms in rheumatic carditis. Lancet $1972 ; 2: 686-688$.

11. Vogt A, Batsford S, Rodriguez-Iturbe B, Garcia R. Cationic antigens in post-streptococcal glomerulonephritis. Clin Nephrol 1983; 20: 271-279.

12. Bergey EJ, Stinson MW. Heparin-inhibitable basement membrane-binding protein of Streptococcus pyogenes. Infect Immun 1988; 56: 1715-1721.

13. van de Rijn I, Kessler RE. Growth characteristics of group A streptococci in a new chemically defined medium. Infect Immun 1980; 27 : 444-448.

14. Johnson DW, Tagg JR, Wannamaker LW. Production of a bacteriocine-like substance by group-A streptococci of $\mathrm{M}$ type 4 and T-pattern 4. J Med Microbiol 1979; 12: 413427.

15. Liu TY, Neumann NP, Elliott SD, Moore S, Stein WH. Chemical properties of streptococcal proteinase and its zymogen. J Biol Chem 1963; 238 : 251-256.

16. Hynes WL, Tagg JR. Role of proteinase in the formation of inhibitory levels of hematin by group A streptococcus cultures on blood-containing media. J Clin Microbiol 1986 23: 929-933. 
17. Petersen GL. A simplification of the protein assay method of Lowry et al. which is more generally applicable. Anal Biochem 1977; 83: 346-356.

18. Lever M. Colorimetric and fluorometric carbohydrate determination with $\rho$-hydroxybenzoic acid hydrazide. Biochem Med 1973; 7: 274-281.

19. Todd JK, Todd BH, Franco-Buff A, Smith CM, Lawellin DM. Influence of focal growth conditions on the pathogenesis of toxic shock syndrome. $J$ Infect Dis $1987 ; 155$ : 673-681.

20. Hirsch A. Growth and nisin production of a strain of Streptococcus lactis. J Gen Microbiol 1951 ; 5: 208-221.

21. Tagg JR, Dajani AS, Wannamaker LW. Bacteriocin of a group B streptococcus: partial purification and characterization. Antimicrob Agents Chemother 1975; 7: 764-772.

22. Tagg JR, Russell C. Bacteriocin production by Streptococcus salivarius strain P. Can J Microbiol 1981; 27: 918-923.

23. Hynes WL, Tagg JR. Proteinase-related broad-spectrum inhibitory activity among group-A streptococci. J Med Microbiol $1986 ; 22: 257-264$

24. Bailey FJ, Hurst A. Preparation of a highly active form of nisin from Streptococcus lactis. Can J Microbiol 1971; 17: 61-67.
25. Sahl H-G, Brandis H. Production, purification and chemica properties of an antistaphylococcal agent produced by Staphylococcus epidermidis. J Gen Microbiol 1981; 127: 377 384.

26. Ellwood DC, Tempest DW. Effects of environment on bacteria wall content and composition. Adv Microb Physiology 1972; 7:83-117.

27. Hurst A, Dring GJ. The relation of the length of the lag phase of growth to the synthesis of nisin and other basic proteins by Streptococcus lactis grown under different cultural conditions. J Gen Microbiol 1968; 50: 383-390.

28. Marquis RE, Mayzel K, Carstensen EL. Cation exchange in cell walls of gram-positive bacteria. Can J Microbiol 1976; 22: 975-982.

29. Groman N, Judge $K$. Effect of metal ions on diphtheria toxin production. Infect Immun 1979; 26 : 1065-1070.

30. Kass EH. Magnesium and the pathogenesis of toxic shock syndrome. Rev Infect Dis 1989; 11 Suppl 1: S167-S175.

31. Reeves MW. Effect of trace metals on the synthesis of toxic shock syndrome toxin 1. Rev Infect Dis 1989; 11 Suppl 1: S145-S150. 